Помиткіна Любов Віталіївна доктор психологічних наук, професор, завідувач кафедри авіаційної психології Національного авіаційного університету, пр. Любомира Гузара, 1, м. Київ, 03058, тел.: (099) 138-4738, e-mail: Lyubvit@ukr.net, https://orcid.org/0000-0002-2148-9728

Жукова Ірина Віталіївна, кандидат наук 3 державного управління, доцент, Виконавчий директор Президії Всеукраїнської асамблеї докторів наук 3 державного управління, Андріївський узвіз, буд.11, оф 68, м. Київ, 04070, тел.: (044) 462-55-41, e-mail: irina_pravo@ukr.net, https://orcid.org/00000003-4927-0610

Пономаренко Тетяна Вадимівна магістр, Міжрегіональна академія управління персоналом, вул. Фрометівська, 2, м. Київ, 03039, тел.: (093) 50048-90, e-mail: ponomarenko1592@gmail.com, https://orcid.org/0000-0001-53955618

\title{
ПСИХОЛОГІЧНІ ОСОБЛИВОСТІ ГРОМАДЯНСЬКОГО ВИХОВАННЯ ЯК СПОСОБУ ФОРМУВАННЯ СВІДОМОСТІ УЧНІВ ПІДЛІТКОВОГО ВІКУ
}

Анотація. Обгрунтовано, що кожному типу суспільства відповідає певний тип освітньої системи, характер педагогічних відносин. Тому розробка психологічної теорії, проєктування психологічних систем і процесів можуть бути успішними лише завдяки чітким уявленням про те, на яких засадах базується взаємодія людини і держави, якого суспільства ми прагнемо, для життя в якій країні готуємо підростаюче покоління, від повторення яких помилок минулого його варто застерегти і що для цього потрібно зробити.

Відмічено, що формування психологічної культури поведінки особистості посідає чільне місце в змісті громадянського виховання, що виявляється в сукупності сформованих соціально-значущих якостей особистості, заснованих на нормах моралі, закону, вчинків людей. Культура поведінки виражає, з одного боку, моральні вимоги суспільства, закріплені в нормах, принципах, ідеалах закону, а з іншого - засвоєння положень, що спрямовують, регулюють і контролюють вчинки та дії людини.

Безперечно, громадянське виховання в сучасному виховному процесі має надзвичайно важливе значення. Повноцінне формування особистості не може позитивно реалізовуватися без громадянської основи. Сьогодні як ніколи важливо спрямовувати дітей і підлітків на вибір громадянськонаціональних ідеалів і ціннісних орієнтацій у їхньому житті. Всебічне виховання підростаючої особистості в наш час не має сенсу без 
громадянського компонента. Ефективність виховання громадянськості, як i багатьох інших особистісних характеристик, значною мірою визначається реалізацією у виховному процесі психологічного підходу, відповідно до якого в структурі особистості виникають і закріплюються передусім ті новоутворення, у «конструювання» яких індивід вкладає свої почуття, власну працю, енергію, конкретну дію, проявляючи цілеспрямовану активність.

Сьогодні, у пору активних демократичних перетворень, ми маємо змогу реалізовувати у виховній практиці ті громадянські надбання, які будуть сприяти вибору активної життєвої позиції та свідомого формування громадянського світогляду наших дітей.

Ключові слова: психологія особистості, громадянське виховання, виховний процес, проєктування психологічних систем, моральні цінності.

Pomytkina Liubov Vitaliivna Doctor of Science, Professor, Head of the Department of Aviation Psychology at the National Aviation University, Liubomyra Huzara Ave., 1, Kyiv, 03058, tel.: (099) 138-47-38, e-mail: Lyubvit@ukr.net, https://orcid.org/0000-0002-2148-9728

Zhukova Iryna Vitaliivna Candidate of Sciences in Public Administration, Associate Professor, Executive Director of the Presidium of the Ukrainian Assembly of Doctors of Sciences in Public Administration, Andriyivskyi Uzviz, Building 11, Office 68, Kyiv, 04070, tel.: (044) 462-55-41, e-mail: irina_pravo@ukr.net, https://orcid.org/0000-0003-4927-0610

Ponomarenko Tetyana Vadymivna Master, Interregional Academy of Personnel Management, Frometivska St., 2, Kyiv, 03039, tel.: (093) 500-48-90; e-mail: ponomarenko1592@gmail.com, https://orcid.org/0000-0001-5395-5618

\section{PSYCHOLOGICAL FEATURES OF CIVIC EDUCATION AS A WAY OF FORMING THE CONSCIOUSNESS OF ADOLESCENT STUDENTS}

Abstract. It is substantiated that each type of society corresponds to a certain type of educational system, the nature of pedagogical relations, so the development of psychological theory, design of psychological systems and processes can be successful only through a clear idea of the principles of human-state interaction. we strive for the life in which country we are preparing the younger generation, from the repetition of which mistakes of the past it should be warned and what needs to be done for this.

It is noted that the formation of the psychological culture of personality behavior occupies a prominent place in the content of civic education, which is manifested in the totality of formed socially significant personality traits based on the norms of morality, law, and human actions. The culture of behavior expresses, on the one hand, the moral requirements of society, enshrined in the norms, principles, ideals of law, and on the other - the assimilation of provisions that guide, regulate and control human actions and deeds. 
Undoubtedly, civic education in the modern educational process is extremely important. Full-fledged formation of personality cannot be positively realized without a civic basis. Today, it is more important than ever to direct children and adolescents to choose civic and national ideals and values in their lives. Comprehensive education of the growing personality in our time does not make sense without the civic component. The effectiveness of citizenship education, as well as many other personal characteristics, is largely determined by the implementation in the educational process of the activity approach, according to which in the structure of personality arise and consolidate primarily those neoplasms in "construction" of which the individual invests his feelings, action, showing purposeful activity.

Today, in the age of active democratic transformations, we have the opportunity to implement in educational practice those civic achievements that will contribute to the choice of an active life position and the conscious formation of the civic worldview of our children.

Keywords: psychology of personality, civic education, educational process, design of psychological systems, moral values.

Постановка проблеми. Процес цілеспрямованого формування особистості передбачає системну підготовку іï до активної участі у виробничому, громадському, культурному, духовному житті, реалізації своїх психологічних, фізичних, інтелектуальних, духовних, творчих, естетичних та інших можливостей, до високоморальної поведінки в суспільстві.

Нині, коли відбувається активний розвиток демократизації держави, громадянське виховання $є$ одним із найважливіших завдань, які розв'язує система освіти. Формується національна демократична держава, й однією 3 передумов iіi існування є лояльний до держави громадянин, що дотримується демократичних цінностей і настанов у своїй поведінці.

Аналіз останніх досліджень та публікацій. Ідеї психологічної складової громадянського виховання завжди були актуальними для освітянської еліти України. Такі відомі українські діячі, як: В. Антонович, Г. Ващенко, Б. Грінченко, М. Грушевський, Дмітрієва О. І. , Помиткіна Л.В. , Савчин М.В. ,Савчук С.В., Смалько О.В., та багато інших, звертали увагу в своїх роботах на особливе значення формування громадянської свідомості підростаючої особистості. «Патріотичне виховання, - підкреслював В. Сухомлинський, - осереддя моральності» [1].

Мета статті - визначити психолого-педагогічні особливості формування громадянського виховання як способу формування свідомості учнів підліткового віку.

Виклад основного матеріалу. Безперечно, у процесі громадянського виховання провідне місце належить психологічній складовій, яка доповнюється й розширюється вихованням у дусі громадянськості. Це поняття об'єднує в собі громадянську, політичну соціалізацію та здатність долучати до цього процесу моральні цінності. 
Сучасні психологи підкреслюють, що виховання громадянина має бути спрямоване передусім на розвиток патріотизму любові до свого народу, до України. Важливою якістю українського патріотизму має бути турбота про благо народу, сприяння становленню й утвердженню України як правової, демократичної держави, готовність відстояти незалежність Батьківщини.

3 патріотизмом органічно поєднується національна самосвідомість громадянина, яка грунтується на національній ідентифікації: вбирає в себе віру в духовні сили своєї нації, ііі майбутнє; волю до праці на користь народу; вміння осмислювати моральні та культурні цінності; історію, звичаї, обряди, символіку; систему вчинків, які мотивуються любов’ю, вірою, волею, осмисленням відповідальності перед своєю нацією [2].

Найважливішою складовою громадянської свідомості $\epsilon$ психологопедагогічні умови розвитку особистості. Вона містить такі гуманістичні риси, як: доброта, увага, чуйність, милосердя, толерантність, совість, чесність, повага, правдивість, працелюбність, справедливість, гідність, терпимість до людей, повага й любов до своїх батьків, роду. Названі якості визначають культуру поведінки особистості.

Значне місце в змісті громадянського виховання посідає формування культури поведінки особистості, що виявляється в сукупності сформованих соціально значущих якостей особистості, що грунтується на нормах моралі, закону, вчинків людини. Культура поведінки виражає, з одного боку, моральні вимоги суспільства, закріплені в нормах, принципах, ідеалах закону, а з іншого - засвоєння положень, що спрямовують, регулюють i контролюють вчинки та дії людини.

У Концепції громадянського виховання особистості підкреслюється, що весь освітній процес в закладах освіти має бути насичений різними аспектами громадянського виховання. Проте особлива роль тут належать предметам соціально-гуманітарного циклу, до них долучаються й предмети художньо-естетичного циклу, а також ті, що входять до варіативного компонента освіти.

Відомий український педагог В. Сухомлинський перший (за радянських часів) звернувся до громадянського виховання як до головної педагогічної проблеми. У 1970 році вийшла його книга «Народження громадянина», де формування громадянськості розглядається одним із основних завдань громадянського виховання та формується, на думку педагога, на основі людяності, гуманізму. Першочерговою умовою формування рис громадянина педагог вважав організацію емоційно насиченого, діяльного (з трудовою основою) життя школи, розвиток громадянської активності кожного індивіда в контексті діяльного життя шкільного колективу. Він визначив молодший шкільний вік як важливий етап для формування громадянина і твердив, що риси громадянина виховуються безліччю впливів педагогічного характеру й некерованими соціальними впливами. Справжнє громадянське виховання, на думку педагога, у процесі навчання починається там, де думка надихає, пробуджує й утверджує прагнення до морального ідеалу [3].

Сучасний педагог Н. Волкова поділяе погляди В. Сухомлинського й 
одним iз критеріїв i результатів громадянського виховання називає громадянськість особистості, яку становлять моральна, політична, правова культура, почуття власної гідності, внутрішньої свободи i водночас вболівання за суспільні ідеали, за пріоритети держави, благо свого народу і його дружні взаємини зі світовим співтовариством [4].

Отже, громадянське виховання - це формування громадянськості як інтегрованої якості особистості, що дає людині можливість відчувати себе морально, соціально, політично i юридично дієздатною та захищеною. Громадянськість - духовно-моральна цінність, світоглядно-психологічна характеристика людини, зумовлена іï державною самоідентифікацією, усвідомлення належності до конкретної країни. Громадянськість - це реальна можливість втілення в життя сукупності соціальних, політичних і громадянських прав особистості, ऑii інтеграція в культурні й соціальні структури суспільства.

Ефективність виховання громадянськості - як і багатьох інших особистісних характеристик - значною мірою визначається реалізацією у виховному процесі діяльнісного підходу, згідно 3 яким у структурі особистості виникають і закріплюються перш за все ті новоутворення, у «конструювання» яких індивід вкладає свої почуття, власну працю, енергію, конкретну дію, проявляючи цілеспрямовану активність. Отже, особистість громадянина формується за умови його реальної включеності в діяльність, коли апробуються, перевіряються на практиці відповідні громадянські цінності.

Основні риси громадянина формуються в молодому віці, під впливом загальнонародних, національних цінностей, у взаємодії особистості 3 суспільством, яке на кожному етапі представляють сім'я, школа, різноманітні колективи.

Громадянське виховання орієнтоване на формування свідомого громадянина, патріота, професіонала, людини зі шляхетними особистісними якостями і рисами характеру, світоглядом і способом мислення, почуттями, вчинками та поведінкою, спрямованими на саморозвиток. В Україні воно зумовлене завданням державотворення на засадах гуманізму, демократії, соціальної справедливості.

Мета громадянського виховання - сформувати свідомого громадянина, патріота, професіонала, тобто людину 3 притаманними особистісними якостями й рисами характеру, світоглядом і способом мислення, почуттями, вчинками та поведінкою, спрямованими на саморозвиток i розвиток демократичного громадянського суспільства в Україні.

Завдання громадянського виховання:

-визнання й забезпечення в реальному житті прав людини як гуманістичної цінності та єдиної норми всіх людей без будь-яких дискримінацій, на чому будується відкрите, демократичне, громадянське суспільство;

-усвідомлення взаємозв'язку між ідеями індивідуальної свободи, прав людини та іiі громадянською відповідальністю; 
-формування національної свідомості, відчуття належності до рідної землі, народу; визнання духовної єдності поколінь і спільності культурної спадщини; виховання почуття патріотизму, відданості в служінні Батьківщині;

-утвердження гуманістичної моралі та формування поваги до таких цінностей, як: свобода, рівність, справедливість.

-формування соціальної активності та професійної компетентності особистості на основі таких соціальних умінь: готовність до участі в процесах державотворення, здатність до спільного життя й співпраці в громадянському суспільстві, готовність узяти на себе відповідальність, здатність розв'язувати конфлікти відповідно до демократичних принципів, здатність до самостійного життєвого вибору на основі гуманістичних цінностей; формування працелюбності особистості, відповідності за свої дії;

- формування політичної та правової культури засобами громадянської освіти, яка дає знання про політичні системи й владу на всіх рівнях суспільного життя, про закони та законодавчі системи; виховання поваги до Конституції України, законодавства, державної мови;

-розвиток критичного мислення, що забезпечує здатність усвідомлювати та відстоювати особисту позицію в тих чи інших питаннях, уміння знаходити нові ідеї та критично аналізувати проблеми, брати участь у дебатах, уміння переосмислювати дії й аргументи, передбачати можливі наслідки дії та вчинків;

-уміння визначати форми та способи своєї участі в житті суспільства, захищати i підтримувати закони та права людини, бути обізнаним зі способом соціального захисту;

-виховання негативного ставлення до будь-яких форм насильства: активне запобігання виявленню деструктивного націоналізму, месіанських настроїв.

Науковий підхід до процесу формування особистості громадянина передбачає, що дія загальних закономірностей розвитку громадянськості опосередковується вПливом конкретно-історичних умов життєдіяльності даного суспільства загалом і кожного з його членів зокрема. Конкретноісторичний підхід допомагає збагнути й сформулювати специфічні, найбільш актуальні на даному етапі розвитку українського суспільства завдання громадянського виховання, а саме:

-усвідомлення громадянами України необхідності державотворчих процесів у поєднанні з розбудовою громадянського суспільства;

-формування у молодого покоління почуття патріотизму, відданості Батьківщині й водночас відчуття належності до світової спільноти.

Громадянське виховання потребує додержання таких принципів:

1. Гуманність i демократичність виховного процесу. Вони означають рівноправність, але диференціацію обов’язків учасників 
виховної взаємодії, їх взаємоповагу, діалогічність, відкритість до сприйманнягромадянських цінностей: щирості, доброти, справедливості, доброзичливості, милосердя тощо.

2. Орієнтація виховного процесу на самоактивацію й саморегуляцію учня. Дотримання їх сприяє розвитку суб'єктних характеристик, формуванню здатності до критичності й самокритичності, до прийняття самостійних рішень, вироблення громадянської позиції, почуття відповідальності.

3. Системність виховного процесу. Цей принцип передбачає гармонійне вживання нових якостей у структуру особистості.

4. Комплексність i міждисциплінарна інтегрованість. Вони передбачають поєднання навчального і виховного процесів, зусиль різних інституцій - сім'ї, дошкільних закладів, школи, громадських спілок, дитячих, молодіжних самодіяльних об'єднань.

5. Наступність і безперервність громадянського виховання. Він полягає в етапності виховання, на кожному 3 яких ускладнюються й урізноманітнюються зміст і напрями розвитку утворень, які становлять цілісну систему громадянських чеснот особистості. Цей принцип діє протягом свідомого життя людини.

6. Культуровідповідність громадянського виховання. Принцип означає єдність громадянського виховання 3 історією та культурою народу, його мовою, народними традиціями та звичаями, які забезпечують духовну спільність, наступність і спадкоємність поколінь.

7. Інтеркультурність виховного процесу. Грунтується він на інтегрованості української та загальнолюдської культури. Полягає у забезпеченні передумов для формування особистості на національному грунті, iï відкритості для інших культур, ідей i цінностей. Лише така особистість здатна зберігати національну ідентичність, бо усвідомлює національну культуру як невід'ємну складову культури світової [4; 5; 6; 7].

Висновки. Отже, у громадянському вихованні особливого значення набуває особистісно-зорієнтований підхід, коли в центрі освітньо-виховного процесу стоять інтереси дитини, іiі психологічні потреби та можливості, права окремого індивіда. Проблему формування психологічної свідомості досліджували і філософи, і психологи, і педагоги, але й до сьогодні вона не втратила своєї актуальності [8].

Психологічна свідомість - одна зі сторін суспільної свідомості, яка у вигляді уявлень i понять відображає реальні відношення й регулює психологічний бік діяльності людини. Специфічною особливістю процесу формування психологічної свідомості є те, що він тривалий і безперервний, а результати його відстрочені в часі. Процес формування психологічно-етичної свідомості динамічний і творчий.

Відмічено, що підлітковий вік - етап розвитку дитини, який відповідає періоду навчання в середній школі. Провідним видом діяльності в даному 
віці стає навчання. У цьому віці продовжують розвиватися самооцінка, мислення, мова, пам'ять, увага, активно розвиваються елементи соціальних почуттів, формуються навички суспільної поведінки.

\section{Лimepamypa:}

1. Кузьмінський A.I. Настільна книга класного керівника: [навч.-метод. пос.] / А.І. Кузьмінський, С.В. Омельяненко. - К.: Знання, 2012. - 262 с.

2. Корнієнко С. Давайте дружити! / С. Корнієнко // Початкова школа. - 2012. №6. - C. 62-63.

3. Куріпта В.І. Людина починається 3 добра / B.I. Куріпта // Розкажіть онуку. 2013. - №17-18. - С. 65.

4. Лисицька Г. Виростай, дитино, й пам'ятай: Батьківщина - то найкращий край! / Г. Лисицька // Початкова школа. - 2013. - №7. - С.59-61.

5. Савчин М.В. Психологія відповідальної поведінки. Монографія. ІваноФранківськ: Місто НB, 2008. 280 c. http://www.library.univ.kiev.ua/ukr/elcat/new/ detail.php3?doc_id=1228292

6. Помиткіна Л.В. Відповідальність як основа правового виховання підлітків в умовах пандемії / Науковий вісник Мелітопольського державного педагогічного університету. Серія: Педагогіка, № 2(25), 2020. C.32-37. https://doi.org/10.33842/22195203/ $2021 / 25 / 32 / 37$

7. Помиткіна Л.В., Помиткін Е.О. Психолого-педагогічний супровід духовнокультурного виховання особистості у XXI столітті / Духовність особистості: методологія, теорія і практика : зб. наук. пр. / За мат-ми Х Міжн. наук.-пр. конф. «Духовно-культурне виховання особистості в умовах входження людства в Епоху Культури» в рамках міжн-го проекту Д. Пола Шафера «Епоха Культури» (30 травня 2019 року, м. Київ); Ч. І. / Гол. редактор Г. П. Шевченко. - Вип. 2 (89).-Сєвєродонецьк: вид-во СНУ ім. В. Даля, 2019. C.153-167.

8. Іван Бахов, Свген Романенко , Ірина Жукова, Анастасія Пасько САНІТАРНОГІГІЄНІЧНІ ВИМОГИ ДО ПРИМІЩЕННЯ ДОШКІЛЬНИХ НАВЧАЛЬНИХ ЗАКЛАДІВ. Наукові перспективи. - № 4(10) 2021. - с. 309-317.

\section{References:}

1. Kuz'mins'kij A.I. Nastil'na kniga klasnogo kerivnika: [navch.-metod. pos.] / A.I. Kuz'mins'kij, S.V. Omel'janenko. - K.: Znannja, 2012. - 262 s.

2. Kornienko S. Davajte druzhiti! / S. Kornienko // Pochatkova shkola. - 2012. - №6. S. 62-63.

3. Kuripta V.I. Ljudina pochinact'sja z dobra / V.I. Kuripta // Rozkazhit' onuku. - 2013. - №17-18. - S. 65.

4. Lisic'ka G. Virostaj, ditino, j pam'jataj: Bat'kivshhina - to najkrashhij kraj! / G. Lisic'ka // Pochatkova shkola. - 2013. - №7. - S.59-61.

5. Savchin M.V. Psihologija vidpovidal'noï povedinki. Monografija. Ivano-Frankivs'k: Misto NV, 2008. $280 \quad$ s. $\quad$ http://www.library.univ.kiev.ua/ukr/elcat/new/detail.php3?doc_id $=1228292$

6. Pomitkina L.V. Vidpovidal'nist' jak osnova pravovogo vihovannja pidlitkiv v umovah pandemiï / Naukovij visnik Melitopol's'kogo derzhavnogo pedagogichnogo universitetu. Serija: Pedagogika, № 2(25), 2020. S.32-37. https://doi.org/10.33842/22195203/2021/25/32/37 
7. Pomitkina L.V., Pomitkin E.O. Psihologo-pedagogichnij suprovid duhovno-kul'turnogo vihovannja osobistosti u HHI stolitti / Duhovnist' osobistosti: metodologija, teorija i praktika : zb. nauk. pr. / Za mat-mi X Mizhn. nauk.-pr. konf. «Duhovno-kul'turne vihovannja osobistosti v umovah vhodzhennja ljudstva v Epohu Kul'turi» v ramkah mizhn-go proektu D. Pola Shafera «Epoha Kul'turi» (30 travnja 2019 roku, m. Kiïv); Ch. I. / Gol. redaktor G. P. Shevchenko. Vip. 2 (89).-Severodonec'k: vid-vo SNU im. V. Dalja, 2019. - S.153-167.

8. Ivan Bahov, Evgen Romanenko, Irina Zhukova, Anastasija Pas'ko SANITARNOGIGIENIChNI VIMOGI DO PRIMIShhENNJa DOShKIL"NIH NAVChAL"NIH ZAKLADIV. Naukovi perspektivi. - № 4(10) 2021. - s. 309-317. 